\title{
27. SHORT-CHAIN ORGANIC ACIDS IN INTERSTITIAL WATERS FROM WESTERN PACIFIC GUYOTS ${ }^{1}$
}

\author{
Janet A. Haggerty ${ }^{2}$ and J. Berton Fisher ${ }^{3}$
}

\begin{abstract}
For the first time, short-chain organic acids are described in interstitial waters from five guyots in the western Pacific. Acetate and malonate were the only organic acids found in the Leg 144 samples. Acetate is a consistent feature of these interstitial waters and is the only organic acid associated with the pelagic cap sediments. Acetate also dominates the organic acid assemblage when malonate is present in clay deposits overlying the volcanic substrate. The organic acids in the Leg 144 interstitial-water samples are compositionally less diverse but richer in acetate concentration than those recorded in interstitial-water samples from the Mariana, Bonin, and Tonga forearcs and the Tonga backarc.

The presence of both ammonium and sulfate and the dominance of acetate in these Leg 144 interstitial waters suggest that organic acids in the midplate guyot setting arise by way of oxidative deamination of sedimentary proteinaceous material.
\end{abstract}

\section{INTRODUCTION}

Short-chain aliphatic acids are frequently found in pore waters from land-based sections in virtually any age of strata. In the marine environment, organic acids are documented only in anoxic pore waters from Holocene nearshore sediments (Parkes and Taylor, 1983), in hydrothermally altered sediments in the actively rifting Guayamas Basin (Martens, 1990), in pore waters associated with serpentine from the Mariana and Bonin forearc seamounts (Haggerty and Fisher, 1992), and in pore waters from the Tonga arc-trench system (Haggerty and Fisher, 1994). The formation of aliphatic acids can occur biochemically (microbial alteration of sedimentary organic matter), chemically (alkaline hydrolysis of sedimentary organic matter in basic microenvironments associated with the hydrolysis of igneous components), or thermally (thermal maturation of sedimentary organic matter). However, all of these processes require a complex organic precursor (Lamar and Goerlitz, 1963; Carothers and Kharaka, 1978; Eglinton et al., 1987; Lundegard and Senftle, 1987; Barth et al., 1988; Haggerty and Fisher, 1992).

The presence of aliphatic acids affects the acid-base chemistry of a pore-water system. Because the types of acids produced are sensitive to oxidation state, they can provide a means of determining the oxidation-reduction conditions. These short-chain organic acids are very soluble in water; therefore, they can represent a significant pathway for transferring reduced carbon back into solution from sedimentary solids.

Leg 144 drilled five guyots, in essentially a north-south orientation, in the western Pacific Basin (see site map preceding title page). All five of the drilled guyots have a cap or a sparse layer of pelagic sediment. At the Leg 144 drill sites, only four of these guyots have pelagic sediment immediately overlying a carbonate platform. A basal clay deposit atop the volcanic substrate usually underlies the carbonate platform (Premoli Silva, Haggerty, Rack, et al., 1993; Haggerty and Premoli Silva, this volume; Holmes, this volume).

Three of the five drilled guyots are located in the Marshall Islands area. Continuous advanced hydraulic piston cores from the pelagic caps of these three guyots yielded unconsolidated nannofossil foraminifer ooze grading downhole into foraminifer ooze (or winnowed,

\footnotetext{
${ }^{1}$ Haggerty, J.A., Premoli Silva, I., Rack, F., and McNutt, M.K. (Eds.), 1995. Proc. $O D P$, Sci. Results, 144: College Station, TX (Ocean Drilling Program).

2 Department of Geosciences, University of Tulsa, 600 South College Avenue, Tulsa, OK 74104. U.S.A.

${ }^{3}$ AMOCO Production Company, P.O. Box 3385, Tulsa, OK 74102, U.S.A.
}

foraminifer sand). The calcium carbonate content is nearly $100 \%$ for these pelagic cap sediments from the Marshall Islands region. Liquefaction occurred when these pelagic carbonate sediments were disturbed; the sandy texture of this sediment resulted in unstable hole conditions. This carbonate ooze recovered from Limalok, Lo-En, and Wodejebato guyots had an extraordinarily high water content and contained only a small percentage of nannofossils and clay - unlike the majority of pelagic carbonate sequences drilled by the Deep Sea Drilling Project (DSDP) and the Ocean Drilling Program (ODP).

The two northernmost guyots drilled on Leg 144 held pelagic sediment with significantly lower calcium carbonate contents. Only one of the three drill holes at Site 878 on MIT Guyot recovered pelagic sediment; the average calcium carbonate content is $71 \%$. These northern pelagic sediments are foraminifer nannofossil ooze that grades downhole into nannofossil ooze in Hole 878A on MIT Guyot, and a sequence of interlayered volcaniclastic sand and foraminifer sand with nannofossil foraminifer ooze and volcanic ash on Takuyo Daisan Guyot at Site 880. One of the objectives of Leg 144 was to determine the diagenetic processes associated with the pelagic sequences.

In this chapter, we describe the occurrence of short-chain aliphatic acids in interstitial waters from sediments drilled at six sites on Pacific midplate guyots. Specifically, we present analyses that differentiate the organic acid assemblage found in pore waters from the pelagic carbonate sediments from the aliphatic acid assemblage associated with sediments immediately overlying the volcanic edifice. We discuss the redox conditions present in this diagenetic environment and suggest an origin for these organic acids as oxidative deamination of organic matter.

\section{METHODS}

Interstitial water was obtained on board the JOIDES Resolution by squeezing sediments in a Carver hydraulic press. Immediately after retrieval of the core on deck, it was cut into sections. Before the core sections were sealed using acetone on plastic end caps, wholeround core samples for inorganic geochemistry were removed by slicing the plastic core tube and capping both ends. Acetone was not used to seal these whole-round core samples. After removal from the plastic core liner and being scraped with a stainless-steel spatula to remove the potentially contaminated outer layer, the sediment samples were placed in a stainless-steel squeezer. Both the squeezer and the sediment samples were handled with plastic gloves to avoid potential contamination. The squeezer was placed in a Carver hydraulic press and squeezed at pressures of up to about 3300 psi. The interstitial water was 
retrieved in a plastic syringe and filtered through a polysulfone filter for removal of fine particles. See the "Explanatory Notes" chapter of the Initial Reports (Premoli Silva, Haggerty, Rack, et al., 1993) for a more detailed description of the extraction of interstitial waters.

An aliquot of the interstitial water was placed in a break-seal ampoule and treated with a few milligrams of 1-hexadecylpyridinium chloride $\left(\mathrm{C}_{21} \mathrm{H}_{38} \mathrm{ClN}\right.$, CAS No. 6004-24-6, Kodak Product No. 05361). The 1-hexadecylpyridinium chloride dissolved in the porewater sample and inhibited bacterial degradation of organic compounds. This quaternary ammonium salt was chosen in preference to $\mathrm{HgCl}_{2}$ because of its lower toxicity to humans. Previous experiments at AMOCO Research Laboratory showed that this salt has the same preservative value for organic acids as $\mathrm{HgCl}_{2}$, and best preservation is achieved when using this salt or $\mathrm{HgCl}_{2}$ in glass containers.

Organic acids were determined using ion exclusion chromatography (IEC: Dionex 2000i series chromatograph, S1 separator, membrane suppressor, $800 \mathrm{mM}$ octanesulfonic acid eluant, tetrabutylammonium hydroxide regenerant, conductivity detection) as described in Haggerty and Fisher $(1992,1994)$ in interstitial-water studies for Legs 125 and 135 . Before injection, sulfate was removed by reacting the sample with excess $\mathrm{BaCl}_{2}(12 \mathrm{mg} / \mathrm{mL}$ sample or $57.6 \mu \mathrm{M} \mathrm{Ba})$, and halides were removed by passing the sample through a silver-formed ion exchange resin (Dionex OnGuard-Ag cartridge). To remove contaminants and condition the packing, the pretreatment cartridge was successively flushed with $5 \mathrm{~mL}$ of distilled water followed by $3 \mathrm{~mL}$ of analyte.

Sample volumes (typically $5 \mathrm{~mL}$ ) were too small to conduct recovery efficiency experiments. Recovery efficiency was evaluated by applying the pretreatment methodology to organic acid standard mixtures and comparing the analytical results for the treated standards to those of the same standard but without pretreatment. Example chromatograms generated from a treated standard, deionized water with preservative, an untreated sample of interstitial water, and a treated sample of interstitial water, are displayed in Haggerty and Fisher (1992). Other analytical details, such as method accuracy and lack of artifact generation, are also discussed in Haggerty and Fisher (1992). In the present study, experimentally determined average recoveries were $95 \%$ and showed no preference for individual acid anions. These recoveries compare directly with those obtained for the pore waters analyzed from Legs 125 and 135 (Haggerty and Fisher, 1992, 1994).

With an eluant flow rate of $0.8 \mathrm{~mL} / \mathrm{min}$, all peaks eluted within $17 \mathrm{~min}$. Observed peaks were identified by matching their retention times to those of verified pure compounds. In addition, some samples were spiked with known organic acids to verify peak identification; one peak remained unidentified. The analyses were targeted for the following organic acids: malonate, formate, acetate, propionate, and butyrate.

\section{RESULTS}

Observed concentrations of determined organic acids are given in Table 1 , as well as the ammonium and alkalinity values determined on board ship and reported in Premoli Silva, Haggerty, Rack, et al. (1993). Organic acids are found in the interstitial waters at all Leg 144 sites studied; acetate is found in nearly all pore-water samples ( 32 of 36 samples). Acetate concentrations are as high as $4051 \mu \mathrm{M}$ and typically are in excess of $200 \mu \mathrm{M}$. Malonate was only found in three samples of pore water from clays that overlie the Limalok volcanic edifice in Hole 871C. Malonate concentrations are between 359 and $124 \mu \mathrm{M}$. In the interstitial-water samples from the basal clay, acetate exceeded the malonate concentrations by approximately an order of magnitude. Formate, propionate, and butyrate were not detected in the Leg 144 samples from the five guyots.

Figure 1 displays the profiles of organic acid concentrations vs. depth for Holes 871A, 871C, 872A, 873B, and 874B. The overall pattern and range of acetate concentration present at all drill holes displayed in Figure 1 are similar. A local concentration maximum appears at approximately 25 to $50 \mathrm{mbsf}$. Three samples from the clays near the base of Hole $871 \mathrm{C}$ have among the highest acetate values recorded for the Leg 144 samples. Samples from the slightly less carbonate-rich pelagic sediments from Holes $878 \mathrm{~A}$ and $880 \mathrm{~A}$ (in the two northernmost guyots drilled on Leg 144) have acetate concentrations that are comparable with those from the carbonate-rich pelagic caps of the Marshall Island guyots.

\section{DISCUSSION}

The maximum concentration of acetate found in the interstitial waters squeezed from pelagic cap sediments is $4.0 \mathrm{mM}$. Assuming complete dissociation of the acetate, this would yield $4.0 \mathrm{mM} \mathrm{H}^{+}$and consequently would be sufficient to dissolve $4.0 \mathrm{mM}$ of $\mathrm{CaCO}_{3}$. Even at the maximum observed concentration of acetate, the organic acids are not sufficient to dissolve a significant quantity of calcium carbonate, although the organic acids may inhibit cementation. A significant alkalinity depletion, indicative of calcium carbonate precipitation, was not observed in the pelagic cap sediments from the Leg 144 guyots (see Table 1). The aliphatic acids in these interstitial waters are present in small quantities and therefore may only be a minor contributory factor rather than a prime factor to explain the exceptionally soupy nature of these pelagic carbonate sediments.

The presence of aliphatic acids impacts the acid-base chemistry of a pore-water system to varying degrees. The alkalinity values presented in Table 1 are relatively constant with increasing depth and were determined by using a Gran titration method (Premoli Silva, Haggerty, Rack, et al., 1993). Considering the highest organic acid concentrations of the Leg 144 interstitial waters, it is conceivable that the aliphatic acids may provide all the alkalinity in the system. Further study and acquisition of independent evidence would be necessary to substantiate this speculation.

\section{Acetate Profiles Related to Physical Property Changes in the Pelagic Cap Sediments}

The localized increase in the acetate concentrations in the pelagic caps at approximately 25 to $50 \mathrm{mbsf}$ (Fig. 1) generally coincides with a change in the physical properties of the sediment as measured on board ship. These changes in the physical properties are interpreted as hiatuses or depositional changes in the sediment. At Site 871, above $25 \mathrm{mbsf}$, the sediment is characterized by higher density values as well as lower porosity and water content values than below $25 \mathrm{mbsf}$. This change in the physical properties coincides with a nondepositional or erosional hiatus between sediments of late and middle Miocene age at approximately 25 mbsf (Premoli Silva, Haggerty, Rack, et al., 1993). The local concentration maximum for acetate at Site 871 appears below this boundary. At Site 872 , some variation is observable in the bulk density of the uppermost $35 \mathrm{~m}$ of pelagic sediment. Two peaks occur: at $8 \mathrm{mbsf}$ and near $28 \mathrm{mbsf}$. In addition, the water content data reveal a trend toward a peak in water content at $50 \mathrm{mbsf}$ and a reduction in water content below that depth. The change at 50 mbsf also coincides with a hiatus between sediments of middle and late Miocene age (Premoli Silva, Haggerty, Rack, et al., 1993). The local increased concentration of acetate at Site 872 occurs near these depths and is associated with changes in the physical properties.

At approximately $25 \mathrm{mbsf}$ at Site 873 , there is a significant late Miocene hiatus, a change in sedimentation rate, a lithologic change from nannofossil foraminifer ooze above to foraminifer ooze below, and an abrupt decrease in the bulk density values below $25 \mathrm{mbsf}$ (Premoli Silva, Haggerty, Rack, et al., 1993). Once again, the local concentration maximum of acetate coincides with these physical changes in the sediment. For these three sites, a local concentration maximum of acetate correlates to the position of hiatuses or depositional changes or both. 
Table 1. Results of malonate, acetate, ammonium, and alkalinity analyses from Leg 144 interstitial waters.

\begin{tabular}{|c|c|c|c|c|c|c|c|}
\hline \multirow{2}{*}{$\begin{array}{l}\text { Core, section } \\
\text { interval }(\mathrm{cm})\end{array}$} & \multirow{2}{*}{$\begin{array}{l}\text { Depth } \\
\text { (mbsf) }\end{array}$} & \multicolumn{2}{|c|}{ Malonate } & \multicolumn{2}{|c|}{ Acetate } & \multirow{2}{*}{$\begin{array}{l}\mathrm{NH}_{4} \\
(\mu \mathrm{M})\end{array}$} & \multirow{2}{*}{$\begin{array}{l}\text { Alkalinity } \\
(\mathrm{mM})\end{array}$} \\
\hline & & $(\mathrm{mg} / \mathrm{L})$ & $(\mu \mathrm{M})$ & $(\mathrm{mg} / \mathrm{L})$ & $(\mu \mathrm{M})$ & & \\
\hline \multicolumn{8}{|l|}{ Limalok Guyot: } \\
\hline $144-871 \mathrm{~A}-1 \mathrm{H}-5,140-150$ & 7.13 & 0.0 & 0 & 125.0 & 2119 & 8 & 2.95 \\
\hline $144-871 \mathrm{~A}-2 \mathrm{H}-6,145-150$ & 16.45 & 0.0 & 0 & 14.2 & 241 & 7 & 3.00 \\
\hline $144-871 \mathrm{~A}-3 \mathrm{H}-5,143-150$ & 24.43 & 0.0 & 0 & 3.5 & 59 & 14 & 2.67 \\
\hline $144-871 \mathrm{~A}-5 \mathrm{H}-2,0-5$ & 37.50 & 0.0 & 0 & 104.1 & 1764 & 8 & 2.49 \\
\hline $144-871 \mathrm{~A}-6 \mathrm{H}-4,140-150$ & 51.40 & 0.0 & 0 & 26.2 & 444 & 6 & 3.26 \\
\hline $144-871 \mathrm{~A}-7 \mathrm{H}-3,142-150$ & 59.42 & 0.0 & 0 & 37.2 & 631 & 11 & 2.64 \\
\hline $144-871 \mathrm{~A}-8 \mathrm{H}-3,142-150$ & 68.92 & 0.0 & 0 & 16.0 & 271 & 10 & 2.74 \\
\hline $144-871 \mathrm{~A}-9 \mathrm{H}-3,143-150$ & 78.43 & 0.0 & 0 & 15.0 & 254 & 7 & 2.75 \\
\hline $144-871 \mathrm{~A}-10 \mathrm{H}-3,145-150$ & 87.95 & 0.0 & 0 & 0.0 & 0 & 7 & 2.77 \\
\hline $144-871 \mathrm{~A}-11 \mathrm{H}-3,143-150$ & 97.43 & 0.0 & 0 & 23.2 & 393 & 8 & 2.69 \\
\hline $144-87 \mathrm{IA}-14 \mathrm{H}-3,143-150$ & 125.93 & 0.0 & 0 & 0.0 & 0 & 7 & 2.74 \\
\hline $144-871 \mathrm{C}-32 \mathrm{R}-3,142-150$ & 426.92 & 26.0 & 252 & 132.3 & 2242 & 49 & 3.30 \\
\hline $144-871 \mathrm{C}-33 \mathrm{R}-2,145-150$ & 435.15 & 12.8 & 124 & 175.0 & 2966 & 17 & 2.50 \\
\hline $144-871 \mathrm{C}-34 \mathrm{R}-2,0-10$ & 443.30 & 37.0 & 359 & 202.7 & 3453 & 50 & 2.87 \\
\hline \multicolumn{8}{|l|}{ Lo-En Guyot: } \\
\hline $144-872 \mathrm{~A}-1 \mathrm{H}-4,145-150$ & 5.95 & 0.0 & 0 & 38.2 & 647 & 125 & 2.62 \\
\hline $144-872 \mathrm{~A}-2 \mathrm{H}-5,145-150$ & 14.95 & 0.0 & 0 & 175.2 & 2969 & 11 & 2.31 \\
\hline $144-872 \mathrm{~A}-4 \mathrm{H}-4,145-150$ & 32.45 & 0.0 & 0 & 95.4 & 1617 & 15 & 2.25 \\
\hline $144-872 \mathrm{~A}-5 \mathrm{H}-5,145-150$ & 43.45 & 0.0 & 0 & 120.1 & 2036 & 5 & 2.27 \\
\hline $144-872 \mathrm{~A}-6 \mathrm{H}-5,140-150$ & 52.90 & 0.0 & 0 & 210.2 & 3563 & 17 & 2.33 \\
\hline $144-872 \mathrm{~A}-7 \mathrm{H}-5,140-150$ & 62.40 & 0.0 & 0 & 25.4 & 431 & 13 & 2.31 \\
\hline $144-872 \mathrm{~A}-8 \mathrm{H}-5,143-150$ & 71.93 & 0.0 & 0 & 46.5 & 788 & 7 & 2.40 \\
\hline $144-872 \mathrm{~A}-9 \mathrm{H}-5,143-150$ & 81.43 & 0.0 & 0 & 17.6 & 298 & 40 & 2.38 \\
\hline $144-872 \mathrm{~A}-10 \mathrm{H}-5,140-150$ & 90.90 & 0.0 & 0 & 20.6 & 349 & 16 & 2,35 \\
\hline $144-872 \mathrm{~A}-11 \mathrm{H}-4,143-150$ & 98.93 & 0.0 & 0 & 0.0 & 0 & 17 & 2.46 \\
\hline $144-872 \mathrm{~A}-14 \mathrm{H}-5,143-150$ & 118.93 & 0.0 & 0 & 79.7 & 1351 & 22 & 2.74 \\
\hline $144-872 \mathrm{~A}-17 \mathrm{H}-2,143-150$ & 142.93 & 0.0 & 0 & 141.3 & 2395 & 39 & 2.63 \\
\hline \multicolumn{8}{|l|}{ Wodejebato Guyot: } \\
\hline 134 & 5.31 & 0.0 & 0 & 23.5 & 398 & 29 & 2.70 \\
\hline 144-873B-2H-5, $135-142$ & 13.71 & 0.0 & 0 & 0.0 & 0 & 28 & 2.60 \\
\hline $144-873 \mathrm{~B}-3 \mathrm{H}-5,145-150$ & 23.01 & 0.0 & 0 & 35.2 & 597 & 57 & 2.59 \\
\hline $144-873 \mathrm{~B}-4 \mathrm{H}-4,140-150$ & 30.88 & 0.0 & 0 & 239.0 & 4051 & 29 & 2.70 \\
\hline $144-873 \mathrm{~B}-5 \mathrm{H}-4,135-140$ & 39.56 & 0.0 & 0 & 236.5 & 4008 & 31 & 2.72 \\
\hline $144-873 \mathrm{~B}-6 \mathrm{H}-4,129-136$ & 49.82 & 0.0 & . & 57.4 & 973 & 50 & 2.67 \\
\hline $144-873 \mathrm{~B}-21 \mathrm{R}-1,140-150$ & 164.20 & 0.0 & 0 & 48.1 & 815 & 116 & 2.95 \\
\hline \multicolumn{8}{|l|}{ MIT Guyot: } \\
\hline IR-2 & 2.49 & 0.0 & 0 & 26.0 & 441 & NA & 2.84 \\
\hline \multicolumn{8}{|l|}{ Takuyo Daisan Guyot: } \\
\hline 144-880A-1H-5, 142-150 & 7.42 & 0.0 & 0 & 30.0 & 508 & NA & NA \\
\hline $144-880 \mathrm{~A}-2 \mathrm{H}-6,142-150$ & 17.69 & 0.0 & 0 & 193.4 & 3278 & $\mathrm{NA}$ & 2.50 \\
\hline
\end{tabular}

Notes: Formate, propionate, and butyrate were not detected in these samples. Ammonium and alkalinity data from Premoli Silva, Haggerty, Rack, et al. (1993). NA = not analyzed; see text for explanation.

Table 2. Comparison of organic acid assemblages derived from interstitial waters squeezed from different materials drilled in midplate, forearc, and backarc environments.

\begin{tabular}{|c|c|c|c|c|c|c|}
\hline Leg & Setting & $\begin{array}{l}\text { Material squeezed } \\
\text { for pore-water sample }\end{array}$ & $\begin{array}{c}\text { Malonate range } \\
\text { (median) }\end{array}$ & $\begin{array}{l}\text { Formate range } \\
\text { (median) }\end{array}$ & $\begin{array}{l}\text { Acetate range } \\
\text { (median) }\end{array}$ & $\begin{array}{l}\text { Propionate range } \\
\text { (median) }\end{array}$ \\
\hline 144 & Midplate guyots & Nannofossil-foraminifer ooze and foraminifer ooze & 0 & 0 & $\begin{array}{l}0-4051 \\
(597)\end{array}$ & 0 \\
\hline 144 & Midplate guyots & Basal clays & $\begin{array}{l}0-359 \\
(252)\end{array}$ & 0 & $\begin{array}{c}815-3453 \\
(2966)\end{array}$ & 0 \\
\hline 125 & Mariana forearc seamount & Serpentine & $\begin{array}{l}0-22 \\
(0)\end{array}$ & $\begin{array}{l}0-2272 \\
(102)\end{array}$ & $\begin{array}{l}0-208 \\
(51)\end{array}$ & $\begin{array}{l}0-68 \\
(0)\end{array}$ \\
\hline 125 & Mariana forearc & Diatom radiolarians, silty clay, and vitric silty clay & 0 & 0 & 0 & 0 \\
\hline 125 & Bonin forearc & Nannofossil marls and nannofossil chalks with volcanic detritus & 0 & 0 & 0 & 0 \\
\hline 135 & Tonga forearc & Clayey nannofossil ooze with vitric sand and vitric silt turbidites & 0 & $\begin{array}{l}0-29 \\
(7)\end{array}$ & $\begin{array}{l}0-10 \\
(0)\end{array}$ & $\begin{array}{l}0-25 \\
(14)\end{array}$ \\
\hline 135 & Tonga backarc & Clayey nannofossil ooze with some beds of volcanic sand and silt & 0 & $\begin{array}{c}0-31 \\
(7)\end{array}$ & $\begin{array}{c}0-53 \\
(0)\end{array}$ & $\begin{array}{l}0-71 \\
(16)\end{array}$ \\
\hline
\end{tabular}

Note: Leg 144 data from this paper; Leg 125 data from Haggerty and Fisher (1992); and Leg 135 data from Haggerty and Fisher (1994).Median values appear in parentheses; all values given in microns $(\mu \mathrm{m})$.

\section{Comparison to Previous Work}

The abundance and representation of aliphatic acid anions found in Leg 144 interstitial waters differ in two ways from all previous ODP interstitial-water samples examined (Table 2) (Haggerty and Fisher, 1992, 1994). First, acetate is the sole monofunctional organic acid in the present Leg 144 assemblages. Therefore, Leg 144 assemblages have the lowest diversity of organic acids of the locations investigated to date. Second, the acetate values are high compared with previous
ODP data. The only comparable site for total abundance of organic acids is Site 780, from Leg 125 , on the summit of a Mariana forearc serpentine seamount. Site 780 also showed the only two previous ODP samples that contained malonate; however, the interstitial waters from Site 780 contained a diverse assemblage of organic acids including formate, acetate, and propionate (Haggerty and Fisher, 1992). These Site 780 interstitial waters were squeezed from serpentine.

Leg 125 samples were also retrieved from sediments associated with the Mariana and Bonin forearc region. The pore waters from 

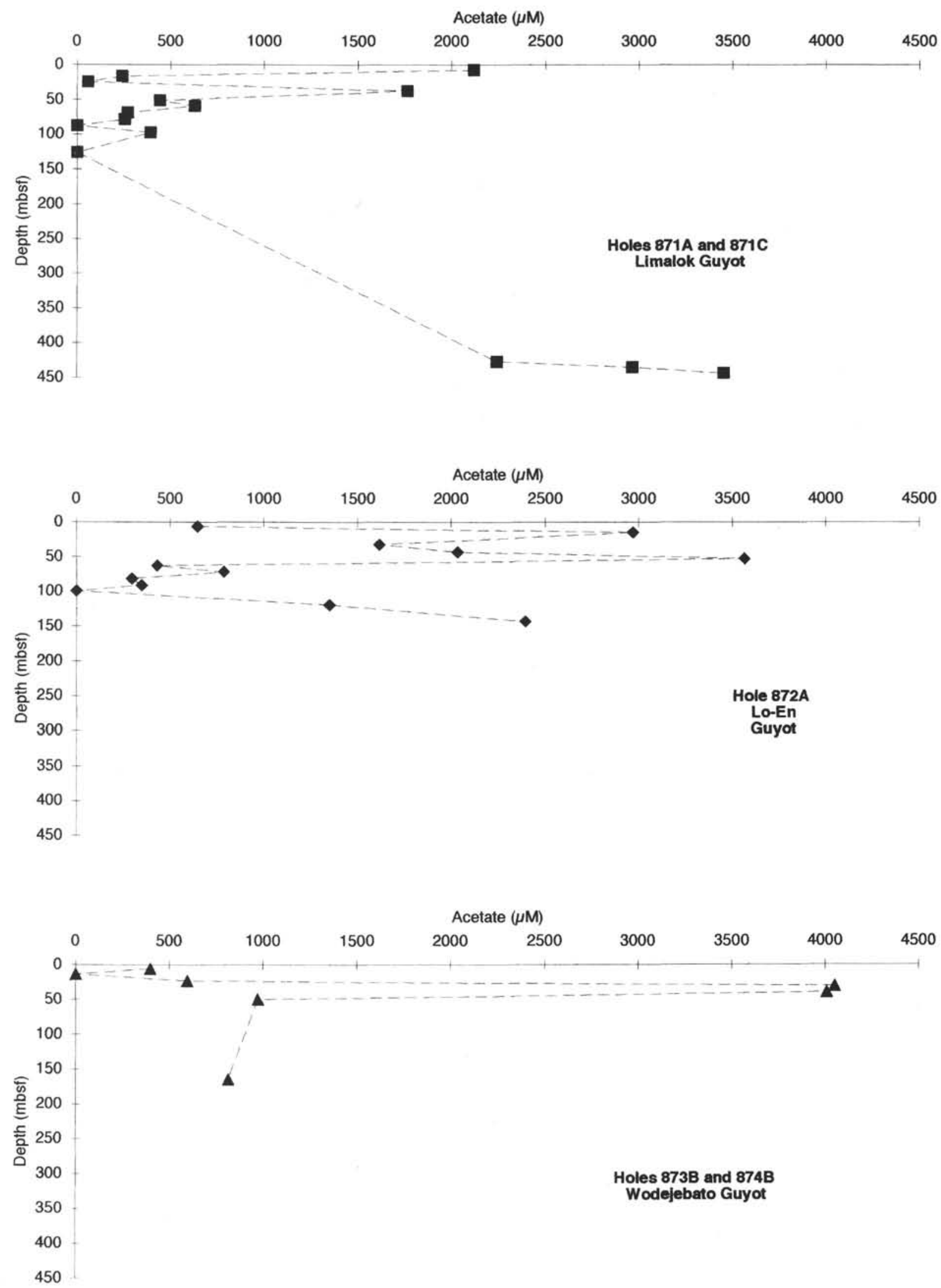

Figure 1. A comparison of the acetate values vs. depth for Limalok, Lo-En, and Wodejebato guyots. See Table 1 for data. 

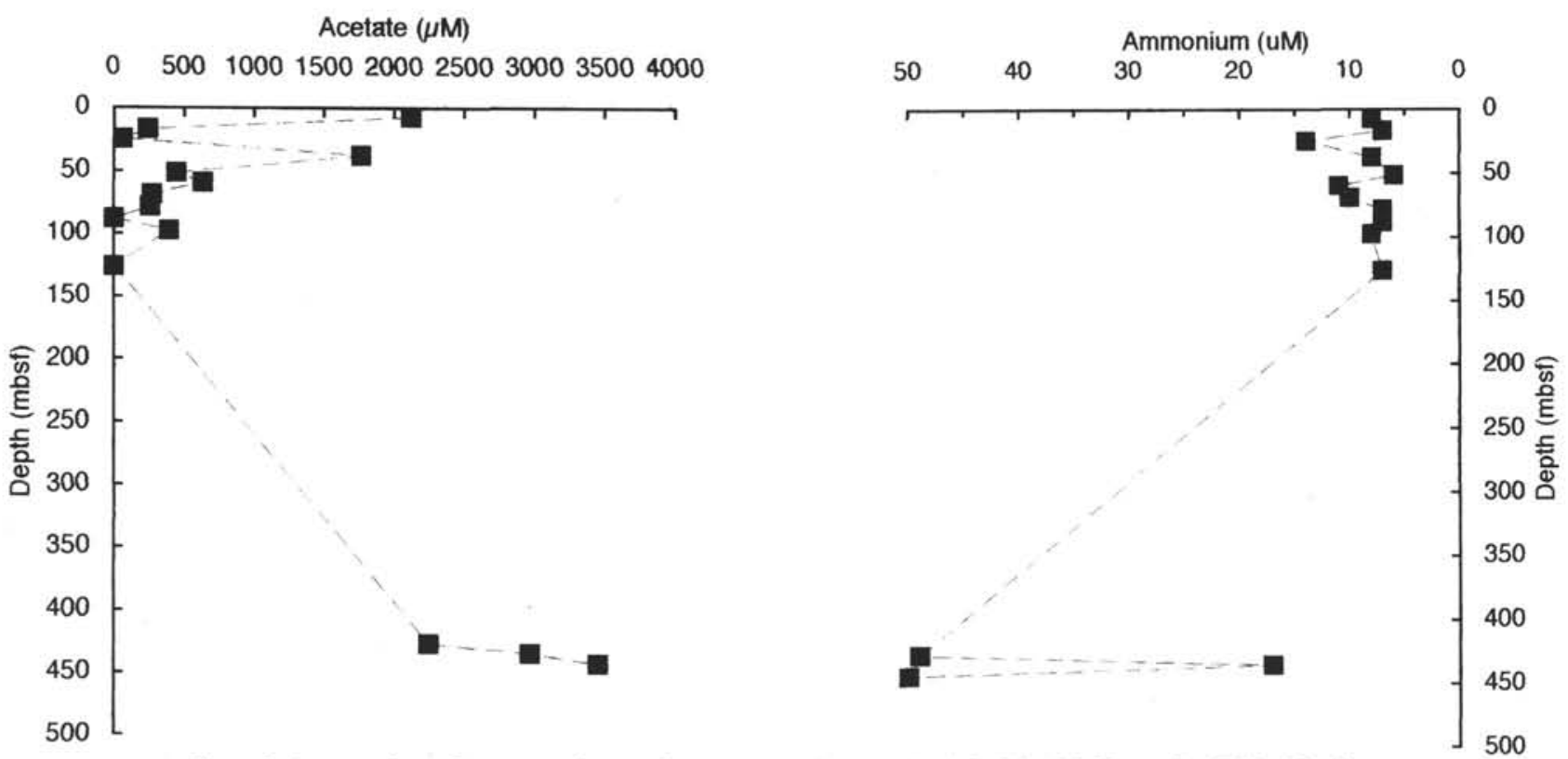

Figure 2. A comparison of acetate and ammonium concentrations vs. depth for Limalok Guyot. See Table 1 for data.

these sediments contained no organic acids (Table 2) (Haggerty and Fisher, 1992). In contrast, the pore waters from Leg 144 pelagic sediments contain abundant acetate.

In comparison to Leg 135 samples from the Tonga arc-trench system, the Leg 144 samples contain an order of magnitude greater total concentration of organic acids and contain no formate or propionate. The organic acid assemblages from Leg 135 backarc basin samples were dominated by propionate. The two Tonga forearc sites also have propionate in higher concentrations than formate; acetate was also observed in 6 of the 17 samples. The organic acid assemblage in these Tonga forearc sediments may not be representative of normal forearc sediments because serpentine was dredged from nearby areas (Haggerty and Fisher, 1994).

Organic acid assemblages from forearc, backarc, and midplate settings are different. Forearc seamount organic acid assemblages, which were derived from interstitial waters squeezed from serpentine, have formate in excess of acetate, with the rare occurrence of threecarbon acids (malonate and propionate). In contrast, the Mariana forearc sediments contain no organic acids. Backarc organic acid assemblages appear to be dominated by propionate, with substantial formate present and the rare occurrence of acetate.

\section{Sources for the Aliphatic Acid Anions}

Regardless of a bacterial, thermal, or chemical mode of origin, the presence of organic acids requires the existence of more complex organic precursors (Lamar and Goerlitz, 1963; Carothers and Kharaka, 1978; Eglinton et al., 1987; Lundegard and Senftle, 1987; Barth et al., 1988; Haggerty and Fisher, 1992). The most likely precursor material for the aliphatic acid anions present in the interstitial waters sampled would be sedimentary organic matter.

Organic carbon is typically found in low concentrations $(0 \%-$ $0.3 \%$ total organic content [TOC]) in sediments associated with the pelagic cap (Premoli Silva, Haggerty, Rack, et al., 1993). Very high concentrations of organic carbon (up to $10.2 \%$ TOC) are found in the clays overlying the volcanic edifice (Premoli Silva, Haggerty, Rack, et al., 1993). Organic characterization analyses from Leg 144 indicate that the organic carbon is derived from organic matter with a low thermal maturity (Premoli Silva, Haggerty, Rack, et al., 1993). In addition, the source of the organic matter in the pelagic cap sediments is mainly autochthonous (linings from foraminifers), whereas the organic matter in the basal clays from Hole $871 \mathrm{C}$ is of terrestrial plant origin (Premoli Silva, Haggerty, Rack, et al., 1993). The terrestrial nature of the organic materials in these basal clays from Hole 871C may be responsible for the presence of the more oxygen-rich malonate in these pore waters.

There is good evidence of bacterial activity at the Leg 144 sites. Ammonium was present in all analyzed interstitial-water samples from Sites 871, 872, 873, 874, and 877. A split of the same interstitialwater sample used in this study was analyzed for ammonium on board ship before the addition of the pickling agent, 1-hexadecylpyridinium chloride $\left(\mathrm{C}_{21} \mathrm{H}_{38} \mathrm{ClN}\right)$. Interstitial-water samples squeezed from three core samples from Hole $878 \mathrm{~A}$ have no ammonium data because of equipment problems on board ship (Premoli Silva, Haggerty, Rack, et al., 1993), whereas the interstitial waters from Sites 879 and 880 were not analyzed for ammonium because of time limitations before port arrival (Premoli Silva, Haggerty, Rack, et al., 1993).

Ammonium in these interstitial waters must have an in situ source because it is readily destroyed under oxidizing conditions. Indeed, pore waters from the basal clays at Site 871 show a minor amount of sulfate depletion. Sulfate contents of the interstitial waters from the pelagic cap are essentially seawater values $(30.22 \pm 1.5 \mathrm{mM})$, whereas pore waters from the three basal clay samples from 427 to $443 \mathrm{mbsf}$ are $27.80 \pm 0.37 \mathrm{mM}$ (Premoli Silva, Haggerty, Rack, et al., 1993). These values would be consistent with the absence of molecular oxygen.

Deamination of amino acids derived from algal and other proteins will produce both organic acids and ammonium (Kuznetsov, 1975). Deamination can proceed by both oxidative and reductive pathways; oxidative deamination yields shorter chain organic acids than reductive deamination (see Kuznetsov, 1975, p. 268). The organic acid assemblage observed in these interstitial fluids displays a predominance of short-chain acids. Despite the evidence for minor sulfate reduction, it appears that the Eh of this diagenetic environment is sufficiently oxidizing to produce an organic acid assemblage characterized by short-chain acids.

If oxidative deamination of amino acids formed short-chain organic acids and ammonium at the Leg 144 sites, then a sympathetic variation should exist between acetate and ammonium. Figure 2 compares the acetate and ammonium data vs. depth for Site 871. There does appear to be a sympathetic variation at this site, although the relationship is not consistent for all data from all sites (see Table 1).

The general thermal immaturity of the organic matter found in cores from Leg 144 suggest that a thermal origin of these organic acid anions is unlikely. There is no evidence for pervasive hydrothermal alteration in these cores (Premoli Silva, Haggerty, Rack, et al., 1993). 


\section{CONCLUSIONS}

The pattern of organic acid anions found in interstitial waters from the western Pacific midplate guyots differs from previously described assemblages observed in ODP materials. In the Tonga arc-trench system, organic acids are present in both sediments and lithified materials, are in much lower abundance when present, and display a pattern in which longer chain acid anions (propionate) dominate over formate, but with acetate rarely present. In the Mariana-Bonin forearcs, organic acid anions are generally absent from interstitial waters squeezed from sediments but are present in the interstitial waters associated with serpentines. In addition, these interstitial waters from serpentine typically have formate present in greater abundance than either acetate or propionate (propionate is rarely present). The Leg 144 organic acid assemblage has the lowest diversity, but the highest concentrations of acetate and malonate of all ODP locations investigated.

Although the organic matter present in all Leg 144 pelagic sediments is described as being in extremely low abundance, it is the most likely source for the acetate found in the Leg 144 interstitial waters from pelagic sediments. Microbial production of the organic acids is the most likely explanation. Ammonium and sulfate are generally present in the Leg 144 interstitial waters. Although molecular oxygen is absent as shown by the presence of ammonium, the continued presence of sulfate indicates that the Eh of the system is not driven to strongly reducing values characteristic of sulfide dominance. Therefore, the sulfate levels present in these waters suggest an environment that is somewhat oxidizing, and the source of ammonium is probably from the deamination of amino acids derived from sedimentary proteinaceous material. Because oxidative deamination would preferentially yield lower carbon number acids compared to reductive deamination, we suggest that oxidative deamination of amino acids is one of the main sources of both the ammonium and organic acids in these interstitial waters.

\section{ACKNOWLEDGMENTS}

The authors thank the Leg 144 Scientific Party and the shipboard personnel of the JOIDES Resolution for collecting the samples. J.A. Haggerty thanks the JOI-USSAC committee for support of the postcruise science, and the NSF EPSCoR program for support of midplate seamount diagenesis studies and forearc serpentine seamount investigations. The authors also thank AMOCO Production Company for access to its analytical water laboratory, and Carl Bennett for his aid during the initial setup of the instrumentation. J.A. Haggerty thanks Kingston University, Surrey, England, where she revised this manuscript while on sabbatical.

\section{REFERENCES}

Barth, T., Borgund, A.E., Hopland, A.L., and Graue, A., 1988. Volatile organic acids produced during kerogen maturation: amounts, composition and role in migration of oil. Org. Geochem., 13:461-465.

Carothers, W.W., and Kharaka, Y.K., 1978. Aliphatic acids in oil field watersimplications for origin of natural gas. AAPG Bull., 62:2441-2453.

Eglinton, T.I., Curtis, C.D., and Rowland, S.J., 1987. Generation of water-soluble organic acids from kerogen during hydrous pyrolysis: implications for porosity development. Mineral. Mag., 51:495-503.

Haggerty, J.A., and Fisher, J.B., 1992. Short-chain organic acids in interstitial waters from Mariana and Bonin forearc serpentines: Leg 125. In Fryer, P., Pearce, J.A., Stokking, L.B., et al., Proc. ODP, Sci. Results, 125: College Station, TX (Ocean Drilling Program), 387-395.

, 1994. Short-chain organic acids in interstitial waters from the Tonga arc-trench system, Leg 135. In Hawkins, J., Parson, L., Allan, J., et al., Proc. ODP, Sci. Results, 135: College Station, TX (Ocean Drilling Program), 709-714.

Kuznetsov, S.I., 1975. The Microflora of Lakes and its Geochemical Activity: Austin, TX (Univ. Texas Press).

Lamar, W.L., and Goerlitz, D.F., 1963. Characterization of carboxylic acids in unpolluted streams by gas chromatography. J. Am. Water Works Assoc., 55:797-802.

Lundegard, P.D., and Senftle, J.T., 1987. Hydrous pyrolysis: a tool for the study of organic acid synthesis. Appl. Geochem., 2:605-612.

Martens, C.S., 1990. Generation of short chain organic acid anions in hydrothermally altered sediments of the Guayamas Basin, Gulf of California. Appl. Geochem., 6:71-76.

Parkes, R.J., and Taylor, J., 1983. Analysis of volatile fatty acids by ion-exclusion chromatography, with special reference to marine pore water. Mar. Biol., 77:113-118.

Premoli Silva, I., Haggerty, J., Rack, F., et al., 1993. Proc. ODP, Init. Repts., 144: College Station, TX (Ocean Drilling Program).

\footnotetext{
Abbreviations for names of organizations and publications in ODP reference lists follow the style given in Chemical Abstracts Service Source Index (published by American Chemical Society).
}

Date of initial receipt: 31 January 1994

Date of acceptance: 8 August 1994

Ms 144SR-048 